\title{
Association of growth and hollow stem development in Shorea albida trees in a tropical peat swamp forest in Sarawak, Malaysia
}

\author{
Yukako Monda $^{1} \cdot$ Yoshiyuki Kiyono ${ }^{2} \cdot$ Auldry Chaddy $^{3} \cdot$ Christopher Damian $^{3} \cdot$ Lulie Melling $^{3}$
}

Received: 27 October 2017 / Accepted: 6 June 2018 / Published online: 11 June 2018

(c) The Author(s) 2018

\begin{abstract}
Key message Shorea albida trees, which grow in oligotrophic tropical peat swamp forests, invest less in defense than growth, and therefore develop tall hollow stems that regrow after breakage.

Abstract The tropical peat swamp forests of Sarawak, Malaysia are low-nutrient soils, but nonetheless have tall Shorea albida trees. Most of these large trees have hollow stems and broken crowns. We examined tree morphology to determine how this species develops and maintains tall above-ground parts in oligotrophic peat soils. We measured hollow diameter at breast height $\left(D_{\text {hollow }}\right)$, tree diameter at breast height $(\mathrm{DBH})$, tree height, and height of breakage of 81 trees. Destructive sampling was also conducted for seven trees, and these data were used to determine wood density and both hollow diameter and stem diameter per meter height. All sampled trees developed hollow trunks before they reach the canopy layer. Linear regression of $D_{\text {hollow }}$ on DBH indicated that the radial expansion rate of the hollow was slightly less than the thickening growth. Stem breakage and crown breakage reduced tree height, but most broken trees regrew from pre-existing upper branches or by epicormic branching. These results suggest that $S$. albida trees devote more resources to growth than defense, and therefore become large with hollow stems.
\end{abstract}

Keywords Construction cost · Growth strategy $\cdot$ Hollow development $\cdot$ Oligotrophic environment $\cdot$ Resource trade-offs Tall trees

\section{Introduction}

Tall trees require significant resources to grow and maintain their large above-ground parts: thick trunks and extensive root systems in particular are needed to provide strength (Gartner et al. 2004; Poorter 2008; Iida et al. 2012). Trees in low-nutrient environment generally produce less biomass per unit photosynthesis than those in high-nutrient environment

Communicated by Y. Sano.

Yukako Monda

monda.yukako.2m@kyoto-u.ac.jp

1 Laboratory of Forest Resources and Society, Graduate School of Agriculture, Kyoto University, Kitashirakawa Oiwake-cho, Sakyo-ku, Kyoto 606-8502, Japan

2 Forestry and Forest Products Research Institute, 1 Matsunosato, Tsukuba, Ibaraki 305-8687, Japan

3 Sarawak Tropical Peat Research Institute, Lot 6035, Kuching-Samarahan Expressway, 94300 Kota Samarahan, Sarawak, Malaysia
(Vicca et al. 2012). Thus, trees in low-nutrient environments are often shorter (Grubb 1977). However, the tropical peat swamp forests of Southeast Asia are oligotrophic, yet support the growth of large dipterocarp trees (Anderson 1961; Whitmore 1975; Yamada 1997).

Shorea albida is a dominant or co-dominant dipterocarp tree in the tropical peat swamp forests in the state of Sarawak, Malaysia, and in Brunei, which have low-nutrient soils (Anderson 1961; Yamada 1997). Maximum diameter at breast height (DBH) of $S$. albida can exceed $100 \mathrm{~cm}$ (Anderson 1972). These trees can reach as high as dipterocarp trees in tropical lowland dipterocarp forests which are among the tallest to grow on mineral soils (Ashton and Hall 1992; Monda et al. 2016). Unlike the trees in tropical lowland dipterocarp forests, most large S. albida trees have hollow stems, and consequently experience crown breakage (Anderson 1961, 1972; Whitmore 1975; Fig. 1a).

Plant structures approach their biomechanical limits within safety margins (Spatz and Bruechert 2000). In general, tall trees with hollow stems experience stem breakage, leading to reduced height and loss of photosynthetic leaves. 



Fig. 1 Hollow stems of a Shorea albida tree with a DBH of $47.7 \mathrm{~cm}$ (a) and of a Combretocarpus rotundatus tree with a DBH of $40.7 \mathrm{~cm}$ (b) in tropical peat swamp forest, Sarawak, Malaysia

However, biomechanical failure occurs only after severe stem hollowing, typically at a hollowness of about $65-70 \%$ (Mattheck et al. 2006). Tree hollows expand mostly into the heartwood, and heartwood has less biomechanical importance than sapwood (Mattheck and Kubler 1997). Thus, small hollows do not significantly affect the structural stability of trees. Stem hollowing in tropical peat swamp forests is due to fungal infections and termites (Anderson 1964; Whitmore 1975). Endogenous chemical defenses against microbial and animal damage to woody parts require substantial metabolic resources (Roxton 2014), with resulting in resource trade-offs between growth and defense. Therefore, allowing stem hollowing, rather than preventing central stem decay, may provide metabolic savings. Moreover, structural and mechanical constraints are major determinants of the height and shape of self-supporting plants, so solid upright stems might become mechanically unstable due to their own weight (Spatz and Bruechert 2000); thus, hollow stems might be more stable than solid stems, simply because they weigh less. Tropical peat swamp forests have peat soil depths of 0.5-20 m (Anderson 1961; Whitmore 1975). Although trees in these sites develop buttress roots and lateral roots, a smaller above-ground biomass (AGB) reduces the risk of subsidence. This suggests that hollow stems may partly explain the presence of tall S. albida trees in nutrient-depleted peat swamp forests.

We studied $S$. albida trees to address two specific questions. First, what is the relationship between stem hollowness and tree size? Second, what strategies do the trees use to grow large?

\section{Materials and methods}

\section{Study area and forest types}

This study was conducted at two peat swamp forest sites in Betong Division, Sarawak, Malaysia: Maludam National Park $\left(01^{\circ} 25.846^{\prime} \mathrm{N}, 111^{\circ} 07.754^{\prime} \mathrm{E}\right)$ and logged peat swamp forest $\left(01^{\circ} 24.218^{\prime} \mathrm{N}, 111^{\circ} 18.411^{\prime} \mathrm{E}\right)$. The Maludam National Park is the largest single patch of peat swamp forest remaining in Sarawak and Brunei. Most of these forests have undergone selective logging, in which trees with DBH more than $45 \mathrm{~cm}$ have been harvested. Logging was banned in the Maludam Peninsula in about 1990, and the site was designated as the Maludam National Park in 2000. This area has a humid and hot climate. Maludam National Park has mean annual precipitation of $2777 \mathrm{~mm}$ and mean annual temperature ranged from 27 to $32{ }^{\circ} \mathrm{C}$ in $2011-2013$ (data from Sarawak Tropical Peat Research Institute).

The peat swamp forest of Sarawak has six types of phasic communities, each with characteristic species and structure due to the topo-hydrological of its peatlands (Anderson 1961) and the fertility of its soils (Sangok et al. 2017), which are highly influenced by hydrology (Melling 2016). We studied three forest types that have many tall trees: phasic community 1 (Type-1) is a Gonystylus-Dactylocladus-Neoscortechinia association (locally known as "mixed peat swamp forest"), Type-2 is a S. albida-Gonystylus-Stenonurus association (locally known as "Alan Batu forest"), and Type- 3 is a $S$. albida consociation (locally known as "Alan Bunga forest"). Nutrient availability decreases from Type-1 to Type-3. Type- 1 generally has shallow peat soil $(<3 \mathrm{~m})$, while both Type-2 and Type-3 have thick peat soils (>10 m) (Melling and Hatano 2004).

The forest structure of Type- 1 is similar to that of a lowland dipterocarp forest, and the canopy layer is between 40 and $50 \mathrm{~m}$ high. Type- 1 has the highest diversity of tree species among the three types in this study, and the dominant trees are Gonystylus bancanus, Dactylocladus stenostachys, and three Shorea species (S. platycarpa, S. scabrida, and S. uliginosa). Shorea albida was present at relatively low densities in Type-1, but dominant in Type-2 and Type-3. 
The forest canopy in Type- 2 is not uniform and is dominated by large $S$. albida trees with DBH values upward of $117 \mathrm{~cm}$ and upper canopy heights up to $70 \mathrm{~m}$. Type- 3 is dominated by $S$. albida with an upper canopy height of $45-60 \mathrm{~m}$, and maximum DBH of $95.5 \mathrm{~cm}$.

\section{Data set 1: hollow diameter at breast height}

Large trees in Sarawak peat swamp forests, such as S. albida have cylindrical hollow stems (Yamada 1997; Monda et al. 2015; Fig. 1a, b). The diameter of the hollow region at breast height $\left(D_{\text {hollow }}, \mathrm{cm}\right)$, in which breast height was defined as $1.3 \mathrm{~m}$ above the ground or $0.3 \mathrm{~m}$ above the buttress root, was used as an index of hollowness. Hollow trunks were determined by core sampling using an increment borer. Two core samples per tree were taken from at positioned at right angle or $180^{\circ}$ to each other. This core sample corresponded to sound tissue thickness (including bark and wood). A hollow trunk was defined as one in which the sum of both core samples was less than the DBH. Shorea albida trees of diverse sizes were selected to cover the entire range of tree sizes likely to be encountered in each forest type of the Maludam National Park. We sampled 81 trees in Maludam National Park (26 trees in Type-1, 32 trees in Type-2, and 23 trees in Type-3). Destructive sampling was conducted in logged peat swamp forest for seven trees in Type- 2 to collect data on hollow diameter per $\mathrm{m}$ height, and $D_{\text {hollow }}$. Details for sampling tree are shown in Table 1.

\section{Data set 2: tree size}

All sampling trees' $\mathrm{DBH}$, tree height, and stem breakage height $\left(H_{\text {breakage }}\right)$ were measured. DBH was determined with a tape measure at $1.3 \mathrm{~m}$ above the ground or $0.3 \mathrm{~m}$ above the buttress root. Tree height and $H_{\text {breakage }}$ were measured with a Vertex IV ultrasonic hypsometer (Haglöf, Långsele, Sweden). Data on stem diameter per $m$ height and DBH were obtained from destructive sampling in logged peat swamp forest (Table 1).

\section{Data set 3: wood density}

Wood density (WD) was calculated using destructive sampling trees in Type-2. One $S$. albida tree (DBH $22.5 \mathrm{~cm}$, solid stem) in this sample grew near the boundary between Type- 2 and Type- 3 . For these measurements, brittle heartwood was defined by the presence of fuzzy end grain in the cross section of a log (after cutting by chainsaw). The boundary between brittle heartwood and sound wood was clear, so WD was calculated separately for these two types of wood, as described by Monda et al. (2015). We also calculated WD using the specific gravity of air-dried wood (15\% water content) and the equation described in Suzuki (1999). The specific gravities of air-dried wood were from data provided by the Tropical Agriculture Research Center (1977). Suzuki's equation was developed using data from the lowland dipterocarp forest of West Kalimantan, Indonesia.

Table 1 Characteristics of sampled trees at the study site

\begin{tabular}{|c|c|c|c|c|c|c|c|}
\hline Species & Stem condition & $\begin{array}{l}\text { Number } \\
\text { of trees }\end{array}$ & $\begin{array}{l}\text { DBH } \\
\text { Min-max }(\mathrm{cm})\end{array}$ & $\begin{array}{l}D_{\text {hollow }} \\
\text { Min-max }(\mathrm{cm})\end{array}$ & $\begin{array}{l}H \\
\text { Min-max (m) }\end{array}$ & $\begin{array}{l}H_{\text {breakage }} \\
\text { Min-max (m) }\end{array}$ & Forest type \\
\hline Combretocarpus rotundatus & Hollow & 2 & $35.0-40.7$ & $22.5-28.9$ & $21.4-22.8$ & $7.0-17.6$ & Type-2 \\
\hline Copaifera palustris & Solid & 1 & 26.2 & 0.0 & 26.5 & ND & Type-2 \\
\hline Dactylocladus stenostachys & Solid & 1 & 35.2 & 0.0 & 26.5 & ND & Type-3 \\
\hline Dillenia pulchella & Hollow & 2 & $41.0-52.0$ & $2.9-22.8$ & $20.9-22.1$ & ND & Type-1 \\
\hline Dillenia pulchella & Solid & 1 & 32.9 & 0.0 & 16.2 & ND & Type-2 \\
\hline Gonystylus bancanus & Hollow & 1 & 37.0 & 7.6 & 28.8 & ND & Type-1 \\
\hline Gonystylus bancanus & Solid & 1 & 43.0 & 0.0 & 28.1 & ND & Type-1 \\
\hline Litsea gracilipes & Hollow & 1 & 21.0 & 4.0 & 21.3 & ND & Type-2 \\
\hline Litsea gracilipes & Solid & 1 & 31.0 & 0.0 & 26.5 & ND & Type-2 \\
\hline Nephelium maingayi & Solid & 1 & 26.5 & 0.0 & 17.6 & ND & Type-2 \\
\hline Palaquium leiocarpum & Solid & 1 & 32.3 & 0.0 & 17.6 & 13.1 & Type-2 \\
\hline Palaquium ridleyi & Hollow & 2 & $46.0-47.5$ & $21.9-33.6$ & $26.9-28.4$ & ND & Type-2 \\
\hline Shorea albida & Hollow & 32 & $17.5-131.1$ & $0.1-110.7$ & $16.3-58.8$ & $8.6-36.0$ & Type- $1,-2,-3$ \\
\hline Shorea albida & Solid & 38 & $9.0-42.7$ & 0.0 & $10.9-30.4$ & $10.6-28.2$ & Type- $1,-2,-3$ \\
\hline Shorea platycarpa & Hollow & 2 & $30.0-57.0$ & $5.3-15.9$ & $23.4-29.9$ & 15.4 & Type-1 \\
\hline Xylopia coriifolia & Solid & 1 & 32.0 & 0.0 & 16.2 & ND & Type-2 \\
\hline
\end{tabular}

Type-1, Gonystylus-Dactylocladus-Neoscortechinia association (Mixed peat swamp forest); Type-2, Shorea albida-Gonystylus-Stenonurus association (Alan Batu forest); Type-3, Shorea albida consociation (Alan Bunga forest)

$D B H$ stem diameter at breast height, $D_{\text {hollow }}$ hollow diameter at breast height, $H$ tree height, $H_{\text {breakage }}$ stem breakage height, $N D$ no $H_{\text {breakage }}$ 
The WD data of Dipterocarpus cornutus and Koompassia malaccensis, which can grow to more than $50 \mathrm{~m}$ in height and are common in the lowland dipterocarp forests of Pasoh Forest Reserve, are from King et al. (2006).

\section{Statistical analysis}

The relationship between $D_{\text {hollow }}$ and DBH for different forest types was analyzed by ANCOVA. Since there are three forest types, Holm's method (Holm 1979) was used to adjust the $P$ values $\left(P_{\text {adj }}\right)$ for multiple comparisons. For trees from the same forest type, we determined the relationship between $D_{\text {hollow }}$ and DBH separately for $S$. albida and other species using ANCOVA; however, this analysis was not performed for Type-3 as only one tree species other than S. albida occurred there. These analyses were applied to the hollow trees in all sampling data. All data were analyzed using $\mathrm{R}$ software for Windows, ver. 3.3.0 (R Core Team 2016).

\section{Results}

\section{Relationship of hollow stems with tree size}

We found hollow stems of Combretocarpus rotundatus, Dillenia pulchella, G. bancanus, Palaquium ridleyi, S. albida, Shorea platycarpa, and partly rotten stems of Litsea gracilipes (Table 1). Hereafter, we refer to tree species other than S. albida as "other species".

All trees in which the DBH was $42.9 \mathrm{~cm}$ or more had hollow stems (Fig. 2). The smallest $S$. albida tree with a hollow stem was found in Type-3 with a DBH of $17.5 \mathrm{~cm}$ and a height of $16.3 \mathrm{~m}$. In Type-1, the smallest tree with a hollow stem had a DBH of $30.0 \mathrm{~cm}$ and a height of $23.4 \mathrm{~m}$; in Type-2, the smallest tree with a hollow stem had a DBH of $20.7 \mathrm{~cm}$ and a height of $20.1 \mathrm{~m}$. Some trees with broken stems regrew lateral or epicormic branches close to the breaking point, in which case the recorded tree height was greater than the $H_{\text {breakage }}$ (Fig. 2). Application of the critical point for structural failure (Mattheck et al. 1994, 2006) to our data indicated that the smallest tree that exceeded this critical point was $40.7 \mathrm{~cm}$ in DBH. However, our data for hollow trees that smallest tree with stem breakage had DBH of $32.0 \mathrm{~cm}$ in Type- $1,27.8 \mathrm{~cm}$ in Type-2, and $17.5 \mathrm{~cm}$ in Type-3. Sixty-nine percent of hollow trees had broken stems, and this percentage varied among the different forest types (Type-1: 30\%; Type-2: 73\%; Type-3: 100\%). The median $H_{\text {breakage }}$ was $17.9 \mathrm{~m}(n=35$, range: 7.0 to $36.0 \mathrm{~m})$.

Analysis of $S$. albida hollow trees yielded the following regression equation: $D_{\text {hollow }}=0.927 \mathrm{DBH}-15.820$ $\left(R^{2}=0.848, F_{1,29}=162.1, P<0.001, n=31\right)$. Analysis of all hollow trees ( $S$. albida and other species) yielded the following regression equation: $D_{\text {hollow }}=0.939 \mathrm{DBH}-17.776$

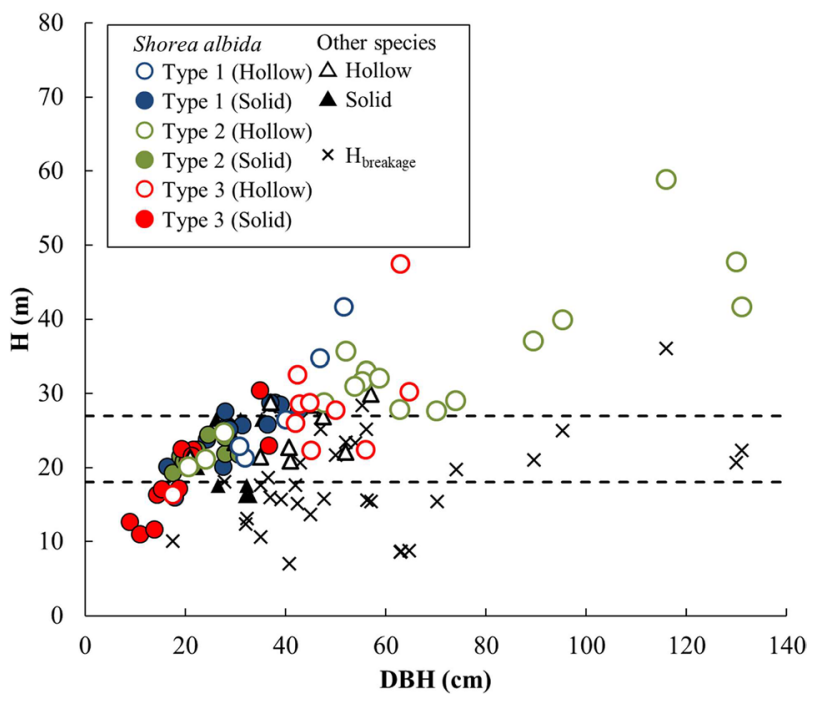

Fig. 2 Relationship of height with diameter at breast height (DBH) of trees that had solid, hollow, and broken stems, and were growing in three different tropical peat swamp forest types in Sarawak, Malaysia. Forest type; Type-1, Gonystylus-Dactylocladus-Neoscortechinia association (Mixed peat swamp forest); Type-2, Shorea albida-Gonystylus-Stenonurus association (Alan Batu forest); Type-3, Shorea albida consociation (Alan Bunga forest). Broken lines indicate the tree height range of the middle canopy layer (18-27 m) as reported by Anderson (1961)

$\left(R^{2}=0.832, F_{1,39}=193.6, P<0.001, n=41\right)$. Within the same forest type, correlation between $D_{\text {hollow }}$ and DBH was similar for $S$. albida and other species (Type-1: $P=0.567$; Type-2: $P=0.498)$. The relationship between $D_{\text {hollow }}$ and DBH did not differ significantly between Type-2 and Type-3 $\left(P_{\text {adj }}=0.10\right)$. However, trees in Type-1 had significantly smaller hollows than type-2 (Y-intercepts, Type-1: 25.947, Type-2: - 14.046; $\left.P_{\text {adj }}<0.01\right)$. Hollow diameter increased more rapidly with tree DBH in Type-3 forests than in Type-1 forests, which means that large trees had thinner stem tissues in Type-3 (slopes, Type-1: 0.303, Type-3: 0.970; $P_{\text {adj }}<0.05$ ).

Among $S$. albida hollow trees, the average sound stem tissue (including bark and wood) thickness at breast height was $10.0 \pm 5.6 \mathrm{~cm}(n=31)$.

We performed destructive sampling of seven trees in Type-2 and found hollows in 4 trees ( 3 S. albida and $1 C$. rotundatus), each of which had a DBH greater than $40.7 \mathrm{~cm}$ and a hollow that passed through the primary stem. These 4 hollow trees had $H_{\text {breakage }}$ of 9-16 m, and the sound stem tissue thickness (including bark and wood) was $6.3 \pm 1.8 \mathrm{~cm}$ (mean \pm standard deviation) (Fig. 4).

\section{Wood density of trees in peat swamp forest and lowland dipterocarp forest}

The WD of S. albida trees in Type- 2 was greater than those in Type-3 except for brittle heart wood in Type-2 (Table 2). 
S. albida tree near the boundary between Type-2 and Type-3 was lower in WD than the $S$. albida in Type-2.

\section{Discussion}

\section{Relationship between stem hollowness and tree size}

We identified hollow stems in all three forest types, and found that all $S$. albida trees with a DBH of $42.9 \mathrm{~cm}$ or more had hollow stems (Fig. 2). Thus, there is a relationship between the presence of hollow stems and DBH in all three forest types. Living trees with hollow stems or rotten cores occur in all types of terrestrial forests, and some previous studies have quantified the hollowness of tree stems (e.g., Wormington and Lamb 1999; Chambers et al. 2001; Koch et al. 2008; Nogueira et al. 2006; N'Dri et al. 2014; McLean et al. 2015; Zheng et al. 2016), including trees in the mixed dipterocarp forests in Sabah and Sarawak, Malaysia (Trockenbrodt et al. 2002; Heineman et al. 2015). There are previous reports of trees with hollow stems in the peat swamp forests in Sarawak and Brunei (Anderson 1961, 1972; Whitmore 1975; Yamada 1997), but there are a few quantitative studies of trees with hollow stems in these forests (Monda et al. 2015). The current study indicates that many S. albida trees in this peat swamp forest have hollow stems, and the extent of stem hollowness is greater than that in other forest types. In $S$. albida trees with DBH of $60 \mathrm{~cm}$ or more, 9 of 10 trees had $D_{\text {hollow }}$ greater than $50 \mathrm{~cm}$. Our data show the height of the tree from the onset of hollow stem formation (DBH $18 \mathrm{~cm})$ to when the hollow stem exists for all trees (DBH $42.9 \mathrm{~cm}$ ) is $16.3-28.5 \mathrm{~m}$ (Fig. 2). The classification of Anderson (1961) indicates that this tree size corresponds to the middle canopy layer in the Sarawak peat swamp forest. Our results suggest that even though $S$. albida trees dominate the upper canopy layer, hollowness develops before these trees reach the canopy layer.

The linear regression between $\mathrm{DBH}$ and $D_{\text {hollow }}$ was significant $(P<0.001)$ and positive (Fig. 3$)$. This suggests that trees with hollow stems continue to increase in diameter, even while interior wood is being lost. The regression of $D_{\text {hollow }}$ on DBH indicates that the expansion rate of the hollow is slightly less than the thickening growth of the trunk (slope of regression: 0.927 in $S$. albida trees; 0.933 in all species). This trend is similar to that from a study in a subtropical forest in China (Zheng et al. 2016). Although the relationship of $D_{\text {hollow }}$ to $\mathrm{DBH}$ in $S$. albida was similar to that in other species within each forest type (Type-1: $P=0.567$; Type-2: $P=0.498), D_{\text {hollow }}$ for a given $\mathrm{DBH}$ varied in across all forest types (Fig. 3). This variation was related to forest type, in that trees growing in more oligotrophic soils (Type-3) tended to form hollows at a smaller DBH (Fig. 2), and $D_{\text {hollow }}$ for a given $\mathrm{DBH}$ was larger in Type-2 and Type-3 than Type-1 ( $D_{\text {hollow: }}$ Type- $1<$ Type- $2, P_{\text {adj }}<0.01$; Type- $1<$ Type- $3, P_{\text {adj }}<0.05$; Type- $2=$ Type- $3, P_{\text {adj }}=0.10$; Fig. 3). In peat swamp forests, forest structure differs among

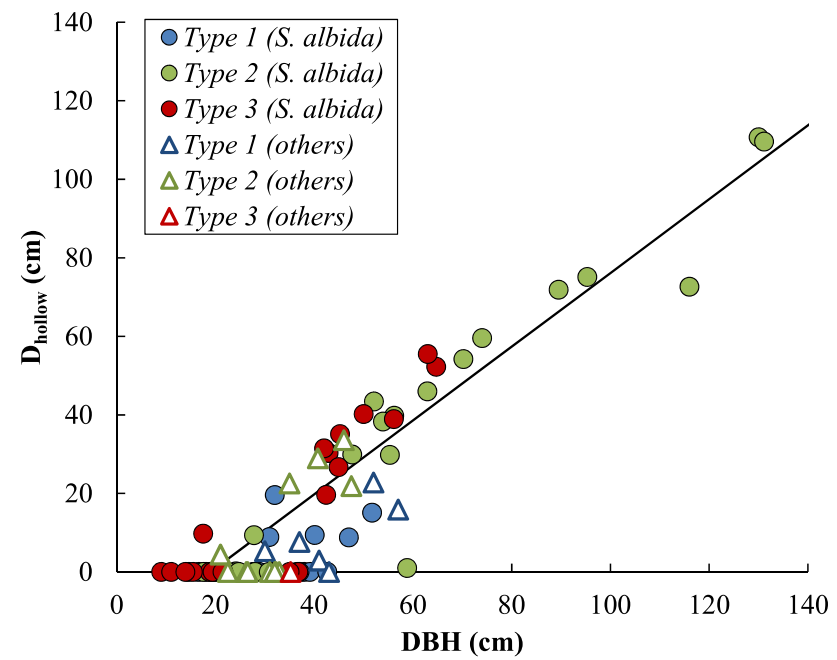

Fig. 3 Hollow diameter at breast height $\left(D_{\text {hollow }}\right)$ versus diameter at breast height $(\mathrm{DBH})$ of $S$. albida and other species growing in the three different forest types. Linear regressions that excluded solid trees $\left(D_{\text {hollow }}=0 \mathrm{~cm}\right)$ were significant (solid line; $R^{2}=0.832, F_{1,39}=$ 193.6, $P<0.001, n=41$ ) (forest types as defined in Fig. 2)
Table 2 Wood density of $S$. albida trees at the study site and of two different tree species in Pasoh Forest Reserve, a lowland dipterocarp forest in Malaysia

\begin{tabular}{lll}
\hline Species (forest type) & Wood density $\left(\mathrm{Mg} \mathrm{m}^{-3}\right)$ & Stem condition and height \\
\hline Shorea albida (Type-2) & $0.563-0.644$ (range) & (i) Hollow trees (H: 27-28 m) \\
& 0.619 (mean) & (ii) no recorded \\
Shorea albida (Type-2) & 0.576 (Sound wood) & (i) Solid tree (H: $21 \mathrm{~m})$ \\
& 0.386 (Brittle heartwood) & (i) Solid tree (H: $21 \mathrm{~m})$ \\
Shorea albida (boundary & 0.349 (Brittle heartwood) & (i) Solid tree (H: 20 m) \\
between Type-2 and Type-3) & & (ii) no recorded \\
Shorea albida (Type-3) & 0.443 (mean) & (iii) Lowland dipterocarp forest $(\mathrm{H}>50 \mathrm{~m})$ \\
Dipterocarpus cornutus & 0.68 & (iii) Lowland dipterocarp forest $(\mathrm{H}>50 \mathrm{~m})$ \\
Koompassia malaccensis & 0.79 &
\end{tabular}

Data sources: (i) Monda et al. (2015); (ii) WD based on data from the Tropical Agriculture Research Center (1977) and the equation of Suzuki (1999); (iii) King et al. (2006) 
forest types (Anderson 1961). Thus, the developmental stage of a tree of a given size may also differ in each forest type, and the properties of woody parts and growth rate change during development. To explain the different patterns of hollow stems in the three forest types, the developmental stage may need to be considered.

\section{Strategies of Shorea albida trees to grow large on the oligotrophic peat soils}

The stability of a hollow tree stem depends on the factors including its material properties (e.g., wood density), crosssectional area (e.g., stem thickness), and other geometric factors (e.g., sound tissues thickness and length of the hollow section).

Trees with high WD usually have greater resistance to physical stress. For species growing in oligotrophic soils, stem rot typically declines as WD increases (Heinenman et al. 2015), although this relationship does not apply to the Amazonian tropical forest (Eleuterio 2011). Larger trees with hollow stems in Type-2 have sound wood with a high WD that provides structural support. However, these tall S. albida had large hollows and a slightly lower WD than the tall trees in Pasoh Forest Reserve (Table 2). Based on mechanical considerations, when a sound tissues is thin, stability decreases as the vertical length of the hollow section increases (Spatz and Niklas 2013). Although S. albida trees have thick stems, these have long hollow sections and thin sound tissues (including bark and wood) (Figs. 3, 4). This indicates that $S$. albida can be as tall as large trees in the lowland dipterocarp forest of Pasoh Forest Reserve (Monda et al. 2016), but $S$. albida is more likely to experience stem and crown breakage. High resistance near the hollow region (data not shown) was found when the hardness of the dried woody part from the bark to the hollow was measured using a wood testing drill (IML-RESI F300, IML Instrumenta Mechanik Labor $\mathrm{GmbH})$. This may indicate the presence of a reaction zone that is resistant to the fungal infection. On the other hand, the thin stem tissues imply insufficient resistance to decay, even though large trees have sound wood. Small trees with solid stems in Type-2 have brittle heartwood in the central core, and the surrounding tissue is sound wood (Table 2). Most S. albida trees in Type-3 were smaller than canopy trees in Type-2, and these smaller trees have inner stems consisting entirely of brittle heartwood (Tropical Agriculture Research Center 1977). The significantly lower WD of this brittle heartwood is caused by internal and/or external stresses that reduces wood strength (Schulte and Schone 1996). In this study, we did not determine whether brittle heartwood was caused by growth stress or fungal infection. In either case, growth of such wood will require fewer plant resources (strength and defense) than growth of wood with high density. Even if the WD is low, strength

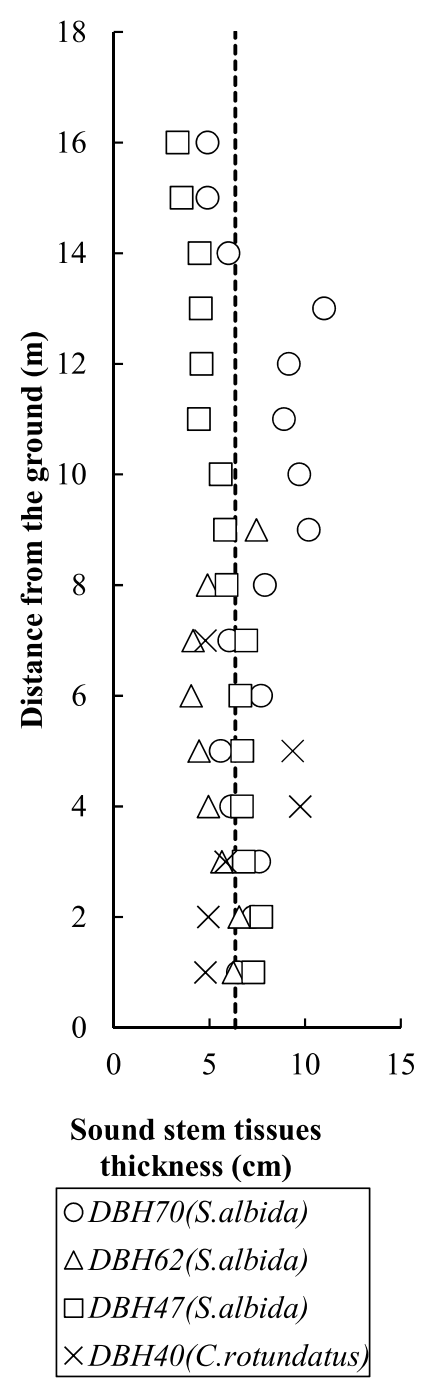

Fig. 4 Relationship between the sound stem tissues thickness (including bark and wood) and distance from the ground of four hollow trees in Type-2. The vertical broken line shows the mean thickness of the residual stem tissues $(6.3 \pm 1.8 \mathrm{~cm})$

can be increased to some extent by increasing stem thickness (Gartner et al. 2004; Pooter 2008; Iida et al. 2012). Our results suggest that $S$. albida employs two strategies to grow large, depending on the level of soil nutrients. In moderately oligotrophic conditions, trees invest in wood strength and stem thickness, but hollow stems develop; in severely oligotrophic conditions, trees invest more in stem thickness than wood strength. Each growth strategy occurs at the expense of investments in stem tissue thickness or wood strength, so these trees may have a little resistance to strong winds (King 1986); consequently, they cannot maintain tall stature in peat swamp forests. Although breakage reduces tree height, we found that most broken trees continued to grow, and a remaining upper branch or epicormic branch substituted for the broken stem or crown (Fig. 2). 
In conclusion, our findings suggest that $S$. albida trees grow large and develop hollow stems because they devote more resources to growth than defense. This may partly explain why stem rot frequency is greater for trees growing in oligotrophic soils.

Author contribution statement MY was the main researcher, designed the research, performed data collection and analysis, and wrote the manuscript. CA and DC contributed to data collection and analysis. KY, ML, and CA helped to improve the discussions, and they provided valuable insights, comments, and corrections to the text.

Acknowledgements We thank Mr. Johnny Kon and Mr. Leong Fad Weng of the Sarawak Timber Association for species identification; Dr. Ryuichi Tabuchi, Dr. Tsutomu Hattori, Dr. Kanako Yamashita, and Dr. Hisashi Abe of the Forestry and Forest Products Research Institute; Dr. Mamoru Kanzaki of Kyoto University; Mr. Frankie Tieh for incisive comments and useful advice; Mr. Mathew Parie, Mr. Lo Kim San and other people in Sarawak who assisted with fieldwork. This research was conducted as part of the Emergency Project to Develop the Structure of Promoting REDD Action, funded by the Forestry Agency of Japan, research program A-0802, and was supported by the Global Environment Fund of the Ministry of the Environment of Japan. This research was supported by Japan Society for the Promotion of Science KAKENHI Grant Number JP17K07841, and the Japan Science and Technology Agency and Collaboration Hubs for International Research Program within the framework of the Strategic International Collaborative Research Program.

\section{Compliance with ethical standards}

Conflict of interest The authors declare that they have no conflict of interest.

Open Access This article is distributed under the terms of the Creative Commons Attribution 4.0 International License (http://creativeco mmons.org/licenses/by/4.0/), which permits unrestricted use, distribution, and reproduction in any medium, provided you give appropriate credit to the original author(s) and the source, provide a link to the Creative Commons license, and indicate if changes were made.

\section{References}

Anderson JAR (1961) The ecological and forest types of the peat swamp forests of Sarawak and Brunei in relation to their silviculture. Dissertation, University of Edinburgh

Anderson JAR (1964) The structure and development of the peat swamps of Sarawak and Brunei. J Trop Geogr 18:7-16

Anderson JAR (1972) Trees of peat swamp forests of Sarawak. Forest Department, Sarawak, Malaysia

Ashton PA, Hall P (1992) Comparisons of structure among mixed dipterocarp forests of North-western Borneo. J Ecol 80(3):459-481

Chambers JQ, dos Santos J, Ribeiro RJ, Higuchi N (2001) Tree damage, allometric relationships, and above-ground net primary production in central Amazon forest. For Ecol Manag 152:73-84

Eleuterio AA (2011) Wood decay in living trees in Eastern Amazonia, Brazil. Dissertation, University of Florida
Gartner BL, Moore JR, Gardiner BA (2004) Gas in stems: abundance and potential consequences for tree biomechanics. Tree Physiol 24:1239-1250

Grubb PJ (1977) Control of forest growth and distribution on wet tropical mountains: with special reference to mineral nutrition. Annu Rev Ecol Syst 8:83-107

Heineman KD, Russo SE, Baillie C, Mamit JD, Chai PPK, Chai L, Hindley EW, Lau BT, Tan S, Ashton PS (2015) Evaluation of stem rot in 339 Bornean tree species: implications of size, taxonomy, and soil-related variation for aboveground biomass estimates. Biogeosciences 12:5735-5751

Holm S (1979) A simple sequentially rejective multiple test procedure. Scand J Stat 6(2):65-70

Iida Y, Poorter L, Sterck FJ, Kassim AR, Kubo T, Potts MD, Kohyama T (2012) Wood density explains architectural differentiation across 145 co-occurring tropical tree species. Funct Ecol $26: 274-282$

King DA (1986) Tree form, height growth, and susceptibility to wind damage in Acer saccharum. Ecology 67(4):980-990

King DA, Davies SJ, Tan S, Noor NSM (2006) The role of wood density and stem support costs in the growth and mortality of tropical trees. J Ecol 94:670-680

Koch AJ, Munks SA, Driscoll D, Kirkpatric JB (2008) Dose hollow occurrence vary with forest type? A case study in wet and dry Eucalyptus oblique forest. For Ecol Manag 255:3938-3951

Mattheck C, Kubler H (1997) Wood-the internal optimization of trees. Springer, Berlin Heidelberg

Mattheck C, Bethge K, West PW (1994) Breakage of hollow tree stems. Trees 9:47-50

Mattheck C, Bethge K, Tesari I (2006) Shear effects on failure of hollow trees. Trees 20:329-333

McLean CM, Bradstock R, Price O, Kavanagh RP (2015) Tree hollows and forest stand structure in Australian warm temperate Eucalytus forests are adversely affected by logging more than wildfire. For Ecol Manag 341:37-44

Mellimg L (2016) Chap. 4 Peatland in Malaysia. In: Osaki M, Tsuji N (eds) Tropical Peatland ecosystems. Springer, Japan, pp 59-89

Melling L, Hatano R (2004) Peat soils study of the peat swamp in the Maludam National Park Betong division Sarawak. Joint Working Group Malaysia — the Netherlands: development and management of Maludam National Park. Malaysia, Sarawak, Alterra

Monda Y, Kiyono Y, Melling L, Damian C, Chaddy A (2015) Allometric equations considering the influence of hollow trees: a case study for tropical peat swamp forest in Sarawak. Tropics 24(1):11-22

Monda Y, Kiyono Y, Melling L, Damian C, Chaddy A (2016) Allometric relations of the trees in the tropical peat swamp forests of Sarawak: influence of hollow stems on tree biomass. In: 15th International Peat Congress 2016 Proceedings. 223-226

N'Dri AB, Gignoux J, Barot S, Konate' S, Dembe'le' A, Werner PA (2014) The dynamics of hollowing in annually burnt savanna trees and its effect on adult tree mortality. Plant Ecol 215:27-37

Nogueira EM, Nelson BW, Fearnside PM (2006) Volume and biomass of trees in central Amazonia: influence of irregularly shaped and hollow trunks. For Ecol Manag 227:14-21

Poorter L (2008) The relationships of wood-, gas- and water fractions of tree stems to performance and life history variation in tropical trees. Ann Bot Lond 102:367-375

R Core Team (2016). R: A language and environment for statistical computing. R Foundation for Statistical Computing, Vienna. http://www.R-project.org/

Ruxton GD (2014) Why are so many trees hollow? Biol Lett-UK 10(11):20140555. http://rsbl.royalsocietypublishing.org/conte $\mathrm{nt} / 10 / 11 / 20140555$ 
Sangok FE, Maie N, Melling L, Watanabe A (2017) Evaluation on the decomposability of tropical forest peat soils after conversion to an oil palm plantation. Sci Total Environ 381-388

Schulte A, Schone D (1996) Dipterocarp forest ecosystems: towards sustainable management. World Scientific Publishing Co. Pte. Ltd. ISBN 981-02-2729-9

Spatz HC, Bruechert F (2000) Basic biomechanics of self-supporting plants: wind loads and gravitational loads on a Norway spruce tree. Forest Ecol Manag 135:33-44

Spatz HC, Niklas KJ (2013) Modes of failure in tubular plant organs. Am J Bot 100(2):332-336

Suzuki E (1999) Diversity in specific gravity and water content of wood among Bornean tropical trees. Ecol Res 14:211-224

Trockenbrodt M, Zamrie I, Josue J (2002) Hollow logs and logging residues from Deramakot Forest Reserve, Sabah, Malaysia. For Ecol Manag 165:141-150

Tropical Agriculture Research Center (1977) Tropical timber trees [Nettai no yuyo jyusyu]. The Tropical Forestry Association of Japan, Tokyo (in Japanese)
Vicca S, Luyssaert S, Penuelas J, Canpioli M, Chapin FSIII., Ciais P, Heinemeyer A, Högberg P, Kutsch WL, Law BE, Malhi Y, Papale D, Piao SL, Reichstein M, Schulze ED, Janssens IA (2012) Fertile forests produce biomass more efficiently. Ecol Lett 15:520-526

Whitmore TC (1975) Tropical rain forests of the Far East. Oxford University Press, London

Wormington K, Lamb D (1999) Tree hollow development in wet and dry sclerophyll eucalypt forest in south-east Queensland, Australia. Aust For 62:336-345

Yamada I (1997) Tropical rainforest of Southeast Asia: a forest ecologist's view. United States of America (ISBN 0-8248-1936-5)

Zheng Z, Zhang S, Baskin C, Baskin J, Schaefer D, Yang X, Yang L (2016) Hollows in living trees develop slowly but considerably influence the estimate of forest biomass. Funct Ecol 30:830-838 